\title{
IDŐSÖDŐ TÁRSADALMAK MINT A TÁRSADALMI INNOVÁCIÓ MOTORJAI
}

\section{SOCIAL INNOVATION IN AGING SOCIETIES}

\author{
Kenesei Zsófia', Kiss Kornélia' ${ }^{2}$ Kolos Krisztina ${ }^{3}$, Kovács Edina ${ }^{4}$, Michalkó Gábor ${ }^{5}$, Sziva Ivett ${ }^{6}$ \\ ${ }^{1} \mathrm{PhD}$, egyetemi tanár, Budapesti Corvinus Egyetem; zsofia.kenesei@uni-corvinus.hu \\ 2PhD, egyetemi docens, Budapesti Corvinus Egyetem; kornelia.kiss@uni-corvinus.hu \\ ${ }^{3}$ PhD, egyetemi tanár, Budapesti Corvinus Egyetem; krisztina.kolos@uni-corvinus.hu \\ ${ }^{4}$ doktorjelölt, Budapesti Corvinus Egyetem; edina.kovacs@uni-corvinus.hu \\ 5az MTA doktora, egyetemi tanár, Budapesti Corvinus Egyetem; gabor.michalko@uni-corvinus.hu \\ ${ }_{6}^{6} \mathrm{PhD}$, egyetemi docens, Budapesti Corvinus Egyetem; ivett.sziva@uni-corvinus.hu
}

\begin{abstract}
ÖSSZEFOGLALÁS
A társadalom idősödésének számtalan következménye van, amellyel szembesülnie kell a gazdaságnak, a szociális és egészségügyi ellátórendszernek, és a társadalom minden egyes tagjának is, életkorától függetlenül. Mindamellett, hogy a legtöbb ország nyugdíjrendszerében gyökeres változások várhatóak, fontosnak tartjuk azokat a folyamatokat is megemlíteni, amelyek nemcsak gazdasági, de társadalmi szempontból is kihívást jelentenek az idősödés során. Cikkünkben összefoglaljuk azokat a lehetőségeket, amelyekkel segíteni lehet az idősödés okozta problémák megoldását, külön figyelmet szentelve a technológia szerepének. Összefoglalónkat a társadalmi innováció gondolata köré szerveztük, amely magában foglalja mindazon új vagy újszerű kezdeményezéseket, amelyek elősegítik a közösség egészének vagy egy hátrányos helyzetű rétege életminőségének és életkilátásainak javítását.
\end{abstract}

\section{ABSTRACT}

There are numerous consequences of ageing societies that create challenges for not only the economic and health care systems but for each member of the society. Besides that pension systems will be dramatically changed in the near future, it is important to focus on the social changes ageing causes. The objective of this paper is to summarize the social challenges and possible solutions of aging societies with a special focus on the role of technology. Social innovations serve as a framework for our investigation, a theory that refers to innovative activities and services meeting a social need that helps to increase the well-being of the society.

Kulcsszavak: idősödés, társadalmi innováció, élethosszig tartó tanulás, robotizáció, elmagányosodás

Keywords: ageing, social innovation, life-long learning, robotisation, loneliness 


\section{BEVEZETÉS}

Az idősödés mára globális jelenséggé vált. Mindamellett, hogy folyamatosan nő a Föld lakóinak száma, azok száma, akik elérik a hatvanéves kort, ennél dinamikusabban nő. Amíg 1950-ben a Föld lakosságának csak 8\%-a volt hatvan év fölött, addig ez a szám 2017-re 13\% volt, és elörejelzések szerint 2050-re 22\% lesz, azaz minden ötödik ember hatvan év fölötti lesz (URL1). Ez a tendencia a fejlett világban ennél jóval erőteljesebben jelentkezik, amit mutat az is, hogy 2012-t az EU a tevékeny időskor támogatásának szánta, és számtalan olyan kezdeményezést indított el, amely segítheti az aktív, jóllétben eltöltött időskor megélését. Magyarországon is több projekt indult el az aktív idősödés támogatásának jegyében (Udvari, 2013), azonban az idősödés komplex mutatóinak tekintetében (Active Ageing Index, Hartford Aging Index) Magyarország még mindig jelentős lemaradásban van, nemcsak a nyugat-európai, de a szomszédos országokhoz képest is. Érdemesnek találjuk tehát összefoglalni azokat a lehetőségeket, amelyekkel segíteni lehet az idősödés okozta problémák megoldását, külön figyelmet szentelve a technológia szerepének.

\section{TÁRSADALMI INNOVÁCIÓ AZ IDŐSEK SZOLGÁLATÁBAN}

A társadalmi innováció fogalma - bár nem újdonság - mégis csak az utóbbi évtizedben került a kutatók érdeklődésének középpontjába. A fogalom maga többféle értelmezésre, megközelítésre ad lehetöséget (Edwards-Schachter-Wallace, 2017; Kocziszky et al., 2017). A magunk részéröl társadalmi innovációnak tekintjük azokat a kezdeményezéseket, amelyek elősegítik a közösség életminőségének és életkilátásainak javítását. Ilyen értelemben társadalmi innováció lehet technológia- vagy nem technológiaalapú, lehet üzleti vagy társadalmi célú, a lényege, hogy egy társadalmi problémára adjon megoldást úgy, hogy képes összességében növelni a közösség jólétét és jóllétét.

A társadalom idősödése olyan komplex és a társadalom minden szegmensét érintő probléma, amely megoldására kreatív, új nézőpont és szektorokon átívelő megoldások szükségesek. A társadalmi innováció szemlélete megfelelő kiindulópontot adhat e megoldások megtalálásában. A következőkben azokat a lehetőségeket foglaljuk össze, amelyek ebből a nézőpontból tekintenek rá az idősödés problémájára, és kínálnak alternatívakat.

\section{"Idősbarát" munkahelyek}

Ahogy az idősödés komplex mutatóiból kiderül, az aktív öregkor egyik legfontosabb dimenziója a munkában aktívan eltöltött évek száma. Sok nyugdíjas korú ember még nagyon is tevékeny, és ha nincs lehetősége a családban, környezetében hasznosítani aktivitását, akkor szívesen maradna még a munkaerőpiacon. Ez a lehe- 
tőség sokaknak nemcsak belső szükséglet, hanem a lecsúszástól, elszegényedéstől való félelemből eredő külső kényszer. A társadalomnak tehát meg kell teremtenie azokat a feltételeket, amelyek lehetővé teszik a nyugdíjas korúak munkavállalását, és számukra kialakított feltételekkel biztosítják a nyugdíjas work-life balance megteremtését. Míg az aktív, munkaképes korú emberek számára ez a kifejezés mindennapossá és elfogadottá vált, ugyanilyen módon kellene az idősek számára is kialakítani a munka-magánélet egyensúlyát lehetővé tévő munkahelyi körülményeket. Ahogy a családos nőknél fontos a részmunkaidő és a rugalmas, otthonról végezhető munka, éppen úgy az idősek számára is fontos szerepe lehetne ezen nem hagyományos foglalkoztatási lehetőségek megjelenésének. Hangsúlyozni szeretnénk, hogy ezek az intézkedések a komplex mutatók egy másik területén is jelentős javulást hozhatnak, ez pedig az idősek anyagi biztonsága és fizikai életfeltételeik javítása.

Ehhez szorosan kötődik az ,idősszenzitív" munkahelyi kultúra létrehozása és kialakítása. Nemcsak a társadalom, hanem a munkaerő is idősödik. Ennek megfelelően, a munkahelyeken is egyre több lesz az időskorú foglalkoztatott, akik másfajta igényekkel, másfajta kihívásokkal állítják szembe a munkaadókat (Adler-Petz, 2011). Ennek megoldása ismét csak össztársadalmi feladat, és olyan innovatív hozzáállást kíván, amely széles teret ad a társadalmi innovációnak. Ahogy ma már létezik „,családbarát” munkahely, úgy szükséges lenne ,,idősbarát” munkahelyeket létrehozni. Ezeken a munkahelyeken a munkakörülmények kialakítása alkalmazkodhat az idősek megváltozott képességeihez (ezek összefoglalása: Székács, 2016), rugalmas nyugdíjazást tehet lehetővé, több egészségügyi ellátást biztosíthat stb. Ezek kidolgozása mind a gazdaságpolitikai döntéshozók, mind a vállalatok számára fontos feladat lesz a jövőben.

\section{Közösségi események}

Itt kell megemlíteni annak a fontosságát, hogy az idős emberek akkor is, ha már nem szeretnének a munkaerőpiacon maradni, szívesen vennének részt társasági tevékenységben vagy akár önkéntes munkában. Fontos feladat lenne olyan társadalmi innovációk kialakítása, amelyek biztosítani tudják a szűk kapcsolatrendszerrel rendelkező és a modern technika adta kommunikációs lehetőségektől elzárt idősek számára a társadalomba való „,visszatérést”, azaz megkeresni azokat a lehetőségeket, amelyekkel segíteni tudják azt az érzést, hogy hasznos tagjai a társadalomnak, és egyben örömteli elfoglaltságot biztosítani számukra. Az idősek kapcsolati hálójának leépülése a kor előrehaladtával egyre jelentősebb. Fontos olyan lehetőségek biztosítása, amelyekkel ezt fenntarthatják, vagy akár újabb kapcsolatokat alakíthatnak ki. Ennek a szervezése nemcsak a helyi állami/ önkormányzati szervezetek feladata, de a helyi közösségek feladata is. Az idősek számára a vallás például fontos színtér, így a vallási élmények, mint a zarándoklatok szervezése jelentős eseménnyé válhat (Mitev et al., 2015). 


\section{Az ellátás biztosítása}

A társadalom számára az egyik legnagyobb kihívás, hogy az egészségügyi ellátó rendszer hogyan alakítható át úgy, hogy képes legyen az egyre növekvő időskorú népesség igényeit ellátni. A jelenlegi egészségügyi rendszerek elsősorban az akut betegségek ellátására alkalmasak, és kevéssé fókuszálnak a krónikus betegségek és betegek ellátására. Ahogy azonban növekszik az idős, várhatóan egészségügyi problémákkal élö emberek száma, az ellátó rendszert ennek megfelelően át kell alakítani. Sajnos a magyarországi egészségügyi adatok fényében, ez Magyarország számára még súlyosabb problémát fog jelenteni az elkövetkező években, hiszen relatíve hosszú a betegen eltöltött évek száma, így egyre növekvő számú ellátandó kerül az egészségügyi rendszerbe. Innovatív megközelítést igényel tehát a probléma megoldása, és olyan, több rendszeren átívelő megoldásokat, amelyek ismét csak komplex megközelítést igényelnek. Szükséges maguknak az ellátó intézményeknek az újragondolása (hosszabb kezelésekre, életvégi ellátásokra alkalmas intézmények, idősotthonok kialakítása), szükséges az ellátást biztosító személyzet (orvosok, ápolók, gondozók) megfelelő képzése és feladatkörük újragondolása, szükséges a finanszírozó rendszer átalakítása (biztosítások, állami ellátások körének kijelölése), illetve a magánegészségügy helyének, szerepének meghatározása a rendszerben.

Az idős emberek, amíg csak lehet, ragaszkodnak ahhoz, hogy saját otthonukban élhessenek (Monostori, 2017). Az idősödés minőségét mérő mutatók egyik fontos eleme, hogy mennyire biztosított az autonóm, önálló élet lehetősége az idős emberek számára. A jövőben megválaszolandó kérdés, hogy hogyan lehet az egyedül élő időseknek segíteni abban, hogy minél tovább tudják élvezni a saját otthonuk biztosította kényelmet anélkül, hogy ezzel egészségi állapotukat veszélyeztetnék. Ez többféle kihívást is jelent a társadalom számára. Egyrészt az idős emberek számára, akik saját otthonukban élnek, biztosítani kell a biztonságos életet, például az otthonok fizikai kialakításával. Ez az a terület, ahol a technológiai innovációnak is nagy szerepe lehet, hiszen az otthonok a modern technikai eszközökkel távolról is irányíthatók és ellenőrizhetők. Másrészt szükséges az otthon élők biztonságos ellátása, amelyre egy külön gondozói hálózatot szükséges kialakítani, hiszen sokszor ezek az idős emberek mozgásukban is korlátozottak.

Habár az idősek a legtöbb országban (így Magyarországon is) szeretnének saját otthonukban maradni, fontos társadalmi kérdés a magányosság problematikája. Amennyiben az idősek egyedül maradnak, nyomasztóvá válhat számukra az egyedüllét. Ez a kérdés az utóbbi években került az érdeklődés középpontjába, miután kutatások bebizonyították, hogy az egyedüllét nagyon fontos egészségügyi kockázati tényező (Cacioppo et al., 2014). Ennek érdekében már több országban indultak kezdeményezések, amelyek kifejezetten az időskorúak elmagányosodását kívánják kezelni (például: telefonvonalak, önkéntes segítőhálózatok, melynek 
tagjai rendszeresen meglátogatják az időseket), de a probléma komplexitása és nagyságrendje új szemléletü megoldásokat kíván.

\section{Élethosszig történő tanulás}

Az élethosszig tartó tanulás koncepciója, habár nevéből eredően az élet végéig kellene hogy tartson, sok esetben mégsem terjed ki az időskorúakra. Még azokban az országokban is, ahol ez a koncepció széles körben elfogadott, leggyakrabban a felnőtt lakosság folyamatos továbbképzésére gondolnak, és nem foglalkoznak az időskorúak számára kialakított oktatási lehetőségekkel. Az időskorúak számára biztosított tanulási lehetőség több területen is segítheti életüket (Bencsik-Trunkos, 2010). Egyrészt segíthet megismerni az idős korral járó élettani folyamatokat, így könnyebbé teheti az adaptálódást az új életszakaszhoz. Másrészt segítheti az alkalmazkodást a gyorsan változó környezethez, különösen a technológiai újdonságok esetében. Harmadrészt - különösen Magyarországon, ahol az idősek alacsonyabb iskolázottsággal rendelkeznek - segíthet pótolni a vágyott, de elmaradt tanulási lehetőséget. Mindezeken kívül a tanulás számukra is a szabadidő hasznos eltöltését jelentheti, ami egyben biztosítja mentális egészségüket, és interperszonális kapcsolataik fenntartását, fejlesztését (Deutsch, 2015). Innovatív megoldások és az oktatási rendszer egészének újragondolása segíthetik e hiányosság kezelését. Ilyenek lehetnek az U3A (University of Third Age) típusú kezdeményezések, mint amilyen például Magyarországon az Eötvös Loránd Tudományegyetem által 2012-ben indított és azóta is rendszeresen előadásokat tartó Harmadik Kor Egyeteme, amely önkéntesek segítségével kifejezetten az időskorúak számára nyújt önképzési lehetőséget.

\section{TECHNOLÓGIAI INNOVÁCIÓK TÁRSADALMI HATÁSAI AZ IDŐSEK KÖRÉBEN}

A társadalmi innováció alatt sok esetben kizárólagosan a nonprofit (tehát társadalmi célú), nem technológiaalapú (tehát szociális, társadalmi rendszerben megjelenő) újításokat értik (Edwards-Schachter-Wallace, 2017). Felfogásunkban a társadalmi innováció ennél sokrétübb, komplexebb fogalom, és az előző részben meghatározott definíció alapján minden olyan újítás, amely a társadalom egy - legtöbbször hátrányos helyzetü - csoportjának életminőségét, lehetőségeit, jóllétét javítja, társadalmi innovációnak tekinthető. Ebben az értelemben a technológiai innovációk fontos szegletét adják a társadalmi innovációknak, amennyiben képesek az összjólétet és jóllétet javítani. Habár a technológia természetesen nem tud minden felsorolt problémára megoldást adni, mégis, a már meglévő és a jövőben várható technológiai újítások az idősek fent megfogalmazott, nagyon sok problémájára tudnak az életminőséget javító megoldásokat adni. 
Infokommunikációs technológiák

Az infokommunikációs újdonságok alkalmazása mára Magyarországon is elterjedt az időskorúak körében, és jelentős segítséget adhat számukra a társadalmi kapcsolatok kialakításában és fenntartásában.

Az internet azok számára, akik használják (44\% a hatvan év fölöttiek körében [URL2]) elsősorban informálódási lehetőséget jelent, másodsorban a szórakozás jelenik meg, harmadrészt pedig a kapcsolattartás platformja. Ez azt is jelzi, hogy egy idős ember számára az internet használata enyhít a magányon, segít a kapcsolatok fenntartásában, ezáltal a társadalmi integráltság fenntartásában akkor is, ha fizikailag már esetleg kevésbé aktív. Az internet ezenkívül abban is segítséget tud nyújtani, hogy olyan tananyagokhoz, szórakoztató szoftverekhez juthassanak hozzá, amelyek segítik szellemi frissességük fenntartását, és egyfajta aktivitási lehetőséget adnak.

Az idősek előszeretettel használják a közösségi médiát is. Bár a YouTube-ot kevesebben, de a Facebookot aktívan használják a hatvan év fölöttiek is. A közösségi médiát saját bevallásuk szerint elsősorban szórakozási céllal látogatják; ugyanezt a médiát a kapcsolatok teremtése és ápolása céljából a középkorúaknak megfelelő százalékban használják (URL3). A magyar idősek körében - ha nem is a fiatalokéval egyenlően, de - ügyeik elintézésében sem ismeretlen az internet, van egy jelentős részük, akik a mindennapokban aktívan hasznosítják ügyintézésre is. A hatvan év fölöttiek az online csatornákat előszeretettel veszik igénybe szolgáltatói ügyintézésre, és - bár kicsit alacsonyabb arányban, mint középkorú társaik - de vásárolnak is interneten keresztül.

\section{Okostechnológiák és robotizáció}

Az okostechnológiák lehetővé teszik az idős emberek távoli ellátását (smart home megoldások), a rendszeres orvosi felügyeletet, illetve annak a felügyeletét, hogy megfelelően bevették-e gyógyszereiket, vagy elvégezték-e napi szükséges rutinjaikat (Demiris et al., 2004). Az MIT AgeLab kutatóközpontja például kifejlesztett egy olyan eszközt (e-Home for Seniors), amely tartalmaz egy hardver és egy szoftver részt. A szoftver segítségével az eszköz használója időzítheti az orvosságok bevételét, erre kérhet figyelmeztetö jelzést, nyomon követheti ő is és családja is a gyógyszerek és kezelések végrehajtását, segíti a családdal való kapcsolattartást, videokonferencia lehetöséget biztosít. A hardver eszköz tartalmaz egy RFID-t és egy mérleget, amely a gyógyszerek mennyiségét ellenőrzi (és ezáltal rögzíti a bevételüket). A technológia továbbfejleszthető akár a fizikai egészségügyi adatok automatikus rögzítésével (vérnyomás, vércukorszint) és orvossal való megosztásával, akár a kifogyott gyógyszerek automatikus utánrendelési funkciójával.

A robotizáció és a mesterséges intelligencia használata a mindennapokban csupán az elmúlt néhány évben vált széles körüvé, és jellemzően a technológiailag je- 
lentős fejlettséget mutató országokban terjedt el, mint például Japán. Mivel Japán az öregedés terén is a super-aging országok közé tartozik, nem véletlen, hogy itt alakultak ki olyan fejlesztések, amelyek a robottechnikát alkalmazzák az öregedés problémáinak legyőzésére. Ezek a robotok mind az ellátásban (personal care and medical robots), mind a társasághiányban (socially assistive robots) kívánnak segíteni az időseknek. Noha a kutatások már elkezdődtek e robotok fogadtatására vonatkozóan, az eredmények egyelőre egymásnak jelentősen ellentmondanak (Pino et al., 2015; Goher et al., 2017).

\section{ÖSSZEGZÉS}

Cikkünkben összefoglaltuk azokat a folyamatokat, amelyek meghatározzák az idősek helyzetét egy olyan társadalomban, amely alapvetően öregszik, így egyre jelentősebb kérdéssé válik, hogy hogyan lehet megőrizni az idős emberek jólétét és jóllétét hosszú távon. Ez a kérdés nemcsak az idős emberek számára fontos, hanem össztársadalmi szempontból is jelentősége van.

A cikkben rámutattunk arra, hogy az elmúlt években népszerűvé vált társadalmi innováció alapú megközelítés hasznos lehet az idősödés problémáinak detektálásában és kezelésében is. A társadalmi innováció ebben a megközelítésben segítheti meghatározni azokat a területeket, ahol szükséges lépéseket tenni, és ebből a szempontból ajánlásokat tudnak megfogalmazni a gazdasági/politikai döntéshozók számára.

A társadalmi innováció fontos területe a technológiai innovációk kialakítása a társadalmi problémák megoldására, jelen esetben az idősödés problémáinak megoldására. Cikkünkben bemutattuk, hogy melyek azok a területek, ahol a technológiai innovációk segíthetnek az idősek problémáinak kezelésében, illetve életminőségük javításában.

\section{KÖSZÖNETNYILVÁNÍTÁS}

Jelen kutatás az Európai Unió, Magyarország és az Európai Szociális Alap társfinanszírozása által biztosított forrásból az EFOP-3.6.2-16-2017-00017 azonosítójú „Fenntartható, intelligens és befogadó regionális és városi modellek” címú projekt keretében jött létre.

IRODALOM

Adler J. - Petz R. (2011): Idősek a pályán: fair a play? Hogyan vélekednek az európai munkaadók az idősebb korosztályok helyéről a jövő munkaerőpiacán? Vezetéstudomány, 17, 6, 25-39. http:// unipub.lib.uni-corvinus.hu/2597/1/vt2011n6p25.pdf 
Bencsik A. - Trunkos I. (2010): „Öreg ember nem vén ember!” avagy Lehetőségeink, esélyeink az élethosszig tartó tanulásra. Vezetéstudomány, 41, 10, 27-39. http://unipub.lib.uni-corvinus. $\mathrm{hu} / 2824 /$

Cacioppo, S. - Capitano, J. P. - Cacioppo, J. T. (2014): Toward a Neurology of Loneliness. Psychological Bulletin, 140, 1464-1504. DOI: 10.1037/a0037618, https://www.ncbi.nlm.nih.gov/pmc/ articles/PMC5130107/

Demiris, G. - Rants, M. J. - Aud, M. A. et al. (2004): Older Adults' Attitudes towards and Perceptions of "Smart Home" Technologies: A Pilot Study. Medical Informatics and the Internet in Medicine, 29, 2, 87-94. DOI: 10.1080/14639230410001684387

Deutsch K. (2015): Élethosszig tartó tanulás. In: Lampek K. - Rétsági E. (szerk.): Egészséges idösödés. Az egészségfejlesztés lehetőségei idős korban. Pécs: Pécsi Tudományegyetem, 143-153. https://www.etk.pte.hu/protected/OktatasiAnyagok/\%21Palyazati/sport2/EgeszsegesIdosodesJ.pdf

Edwards-Schachter, M. - Wallace, M. L. (2017): 'Shaken, but not stirred': Sixty Years of Defining Social Innovation. Technological Forecasting and Social Change, 119, 64-79. DOI: 10.1016/j. techfore.2017.03.012

Európai Bizottság (2012): Tevékeny időskor és nemzedékek közötti szolidaritás - az EU támogatásával. Luxemburg: Európai Unió Kiadóhivatala, https://publications.europa.eu/en/publication-detail/-/publication/5f78f31d-1cac-4263-a76d-7077555349da/language-hu

Goher, K. M. - Mansouri, N. - Fadlallah, S. O. (2017): Assessment of Personal Care and Medical Robots from Older Adults' Perspective. Robotics Biomimetics, 4, 1, DOI: 10.1186/s40638-0170061-7, https://www.ncbi.nlm.nih.gov/pmc/articles/PMC5606957/

Kocziszky Gy. - Veresné Somosi M. - Balaton K. (2017): A társadalmi innováció vizsgálatának tapasztalatai és fejlesztési lehetöségei. Vezetéstudomány, 48, 6-7, 15-19. https://core.ac.uk/ download/pdf/85128978.pdf

Mitev A. - Irimiás A. - Michalkó G. (2015): Halászkirályok hanghullámai: az idősek vallási eseményekhez kapcsolódó élményeinek megértése. Vezetéstudomány, 46, 4, 23-34. http://unipub. lib.uni-corvinus.hu/1889/1/vt_2015n4p23.pdf

Monostori J. (2017): Stabilitás és változás az idősek háztartásszerkezetében. Demográfia, 60, 1, 105-137. DOI: 10.21543/Dem.60.1.3. http://www.demografia.hu/kiadvanyokonline/index.php/ demografia/article/download/2707/2590

Pino, M. - Boulay, M. - Jouen, F. et al. (2015): Are We Ready for Robots That Care for Us? Attitudes and Opinions of Older Adults toward Socially Assistive Robots. Frontiers in Aging Neuroscience, 7:141. DOI: 10.3389/fnagi.2015.00141, https://dx.doi.org/10.3389/fnagi.2015.00141

Székács B. (2016): Megöregedni ma... és holnap? Mit tehetünk a máért, mit a holnapért? Demográfia, 59, 2-3, 155-172. DOI: 10.21543/dem.59.2-3.1, http://www.demografia.hu/kiadvanyokonline/index.php/demografia/article/download/1/2561

Udvari A. (2013): Tevékeny élet időskorban is - 2012 a tevékeny időskor és a nemzetek közötti szolidaritás éve. Kapocs, 12, 1, 26-39., 12, 2, 30-37. http://epa.oszk.hu/02900/02943/00056/pdf/ EPA02943_kapocs_2013_1_26-39.pdf, http://epa.oszk.hu/02900/02943/00057/pdf/EPA02943_ kapocs_2013_2_30-37.pdf

URL1: World Population Prospects, https://population.un.org/wpp/

URL2: NMHH 2017 Lakossági internethasználat 2017, http://nmhh.hu/cikk/195101/Lakossagi_internethasznalat_2017

URL3: NMHH 2016 Lakossági internethasználat, 2016, http://nmhh.hu/cikk/187547/Lakossagi_ internethasznalat_2016 